Section Editor

Mitchell S.V. Elkind, MD, MS
Address correspondence and reprint requests to Dr. Amélia Mendes, Neurology Department of Hospital de S. João, Alameda Hernâni Monteiro, 4200 Porto, Portugal

mendes.amelia@gmail.com

\title{
Teaching NeuroImages: \\ Neuropathy caused by Mycobacterium leprae
}

A 52-year-old Brazilian woman presented with numbness and paresthesias in both feet for 6 months. Clinical history revealed nonspecific discomfort in her right foot and recurrent red spots on abdomen and back for 4 years. Examination disclosed cutaneous lesions (figure 1) and EMG showed a chronic, mainly sensory axonal polyneuropathy. Biopsy was diagnostic of leprosy neuropathy (figure 2). After starting multidrug therapy, cutaneous lesions improved and the neuropathy remained stable.

Leprosy, the most treatable form of peripheral neuropathy, must be considered in the differential diagnosis of neuropathies with cutaneous lesions, especially if sensory fibers are the most involved. ${ }^{1}$

\section{AUTHOR CONTRIBUTIONS}

Dr. Mendes: drafting/revising the manuscript, analysis or interpretation of data. Dr. Abreu: drafting/revising the manuscript, analysis or interpretation of data. Dr. Oliveira: drafting/revising the manuscript. Dr. Castro: drafting/revising the manuscript, analysis or interpretation of data. Dr. Carpenter: drafting/revising the manuscript, analysis or interpretation of data, photography.

\section{REFERENCE}

1. Panezai S, Saleh FG. Leprosy and peripheral neuropathy. J Clin Neuromuscul Dis 2004;5:138-145.

\section{Figure 1 Discoloration of the skin compatible with} leprosy cutaneous lesions (arrows)

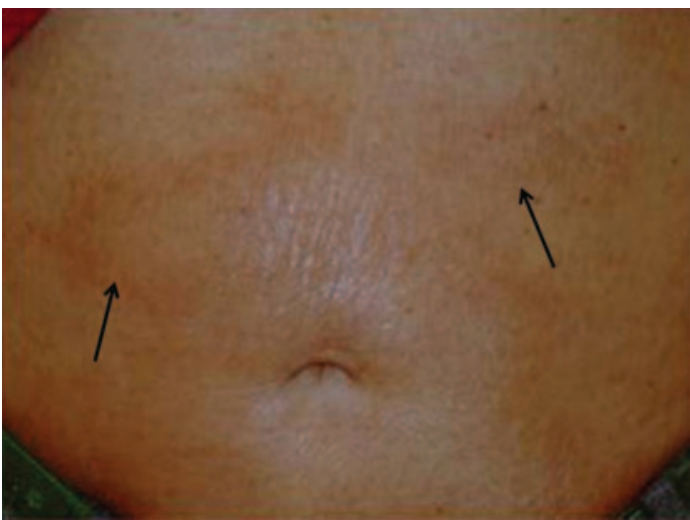

\section{Figure 2 Toluidine blue (A, B) and Fyte stain (C, D)}
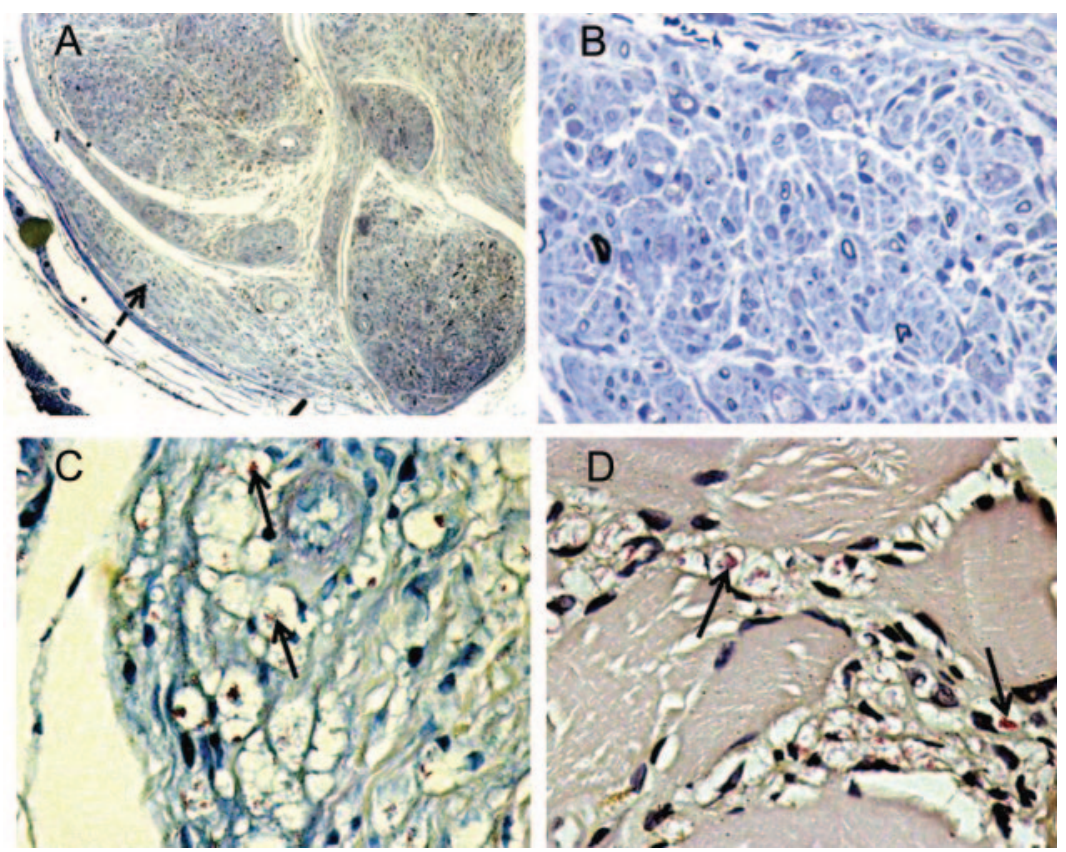

(A) Inflammatory cells and fibroblasts have proliferated in the subperineurial space (dashed arrow). (B) Extensive loss of myelinated fibers. (C) Vacuolated cells at the edge of a nerve fascicle contain bacilli (arrows). (D) Muscle showed focal accumulations of bacilli in macrophages (arrows). 


\section{Neurology}

\section{Teaching NeuroImages: Neuropathy caused by Mycobacterium leprae}

A. Mendes, P. Abreu, A. Oliveira, et al.

Neurology 2011;77; 37

DOI 10.1212/WNL.0b013e318228befc

\section{This information is current as of August 8, 2011}

\section{Updated Information \&} Services

\section{References}

Subspecialty Collections

Permissions \& Licensing

Reprints including high resolution figures, can be found at: http://n.neurology.org/content/77/6/e37.full

This article cites 1 articles, 0 of which you can access for free at: http://n.neurology.org/content/77/6/e37.full\#ref-list-1

This article, along with others on similar topics, appears in the following collection(s):

All Clinical Neurology

http://n.neurology.org/cgi/collection/all_clinical_neurology All Infections

http://n.neurology.org/cgi/collection/all_infections

Bacterial infections

http://n.neurology.org/cgi/collection/bacterial_infections

Peripheral neuropathy

http://n.neurology.org/cgi/collection/peripheral_neuropathy

Information about reproducing this article in parts (figures,tables) or in its entirety can be found online at:

http://www.neurology.org/about/about_the_journal\#permissions

Information about ordering reprints can be found online:

http://n.neurology.org/subscribers/advertise

Neurology ${ }^{\circledR}$ is the official journal of the American Academy of Neurology. Published continuously since 1951, it is now a weekly with 48 issues per year. Copyright Copyright @ 2011 by AAN Enterprises, Inc.. All rights reserved. Print ISSN: 0028-3878. Online ISSN: 1526-632X.

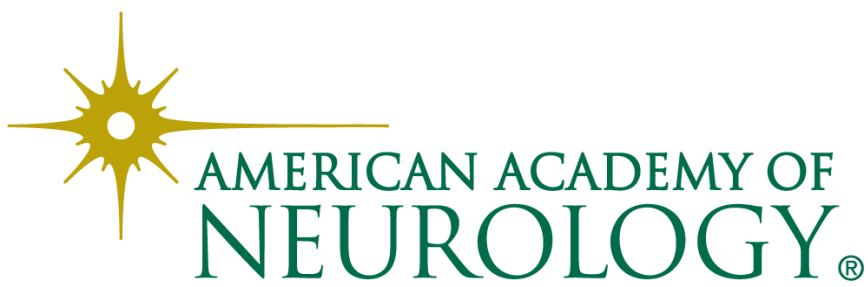

